\title{
Benefits of Installing a Photovoltaic Power-Generation System for a Warehouse Facility
}

\author{
Michalene Grebski \\ Northampton Community College, Monroe Campus, USA \\ Anna Maryniak \\ Poznan University of Economics \\ and Business, Poland
}

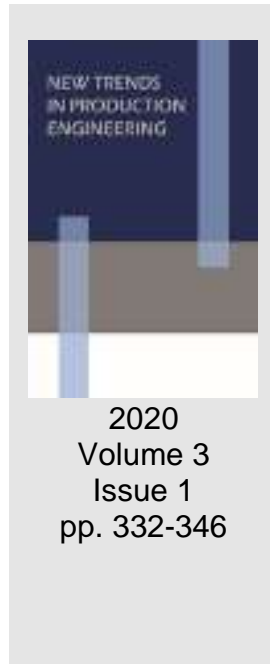

Date of submission to the Editor: 02/2020

Date of acceptance by the Editor: 03/2020

\section{INTRODUCTION}

The construction of warehouses with the application of solutions conducive to environmental protection is part of the ideas of sustainable development, sustainable supply chain as well as green construction (also known as ecological construction or eco-construction). The assessment of warehouses in terms of sustainability can be considered from the perspective of economic and societal benefits, the competitiveness of supply chains and the functioning of a business based largely on warehouse management. Sustainable warehouses are considered an integral part of sustainable supply chains (He et al., 2019; Mangina et al., 2020; Maryniak, 2017; Moktadir, 2019; Rajesh 2020, Yadav et al., 2020).

An analysis of world literature includes numerous studies on sustainable activities in vertically integrated entities. These are studies on aspects of transport optimization, the use of ecological rolling stock, aspects related to the configuration of the supply chain and the introduction of sustainable activities in the production environment, including supply, production and reverse logistics. Some of the tasks undertaken are based on such standards as EMAS (Eco-Management and Audit Scheme), SA8000, AA1000 (Account-Ability), GRI (Global Reporting Initiative), GC (Global Compact), and their effects are reported in various types of reports such as: environmental statement, sustainability report, social report, sustainability report, environmental statement and environmental report.

"Sustainable magazine" is a broader concept than "green magazine" because, in addition to environmental aspects, it also includes social and economic aspects. At the same time, it is a narrower concept in relation to the term "corporate social responsibility" because it applies only to sustainable enterprises implemented in the process of customer logistic service. 
The range of activities that include the idea of a sustainable magazine is very wide. These include the following:

- building an intelligent system for measuring and monitoring the consumption of energy, water, gas and other utilities,

- the use of ecological materials for construction from the local market, ecological materials with high insulation parameters,

- the use of low-emission internal racking,

- transport infrastructure (locating objects closer to ports, suppliers or customers to reduce the carbon footprint),

- taking care of the low level of generated waste,

- using tools for air purification,

- maintaining an optimal temperature,

- increasing the level of ergonomics at work,

- optimizing lighting, inter alia, by "letting natural light" into the warehouse as it affects greater work efficiency,

- use of returnable plastic containers, going for "net-zero", i.e. producing as much energy as the building consumes by building a renewable energy strategy.

On the one hand, the green magazine is a rare domain of business practice. In addition, it is still a poorly explored research field. This is reflected in the empirical research of the business environment, in the number of magazines covered by environmental certification and in research results in scientific publications. For example Ciliberti, Pontrandolfo and Scozzi (2008) found that among the sustainable activities in the supply chain, warehouse management is the least developed (Figure 1).

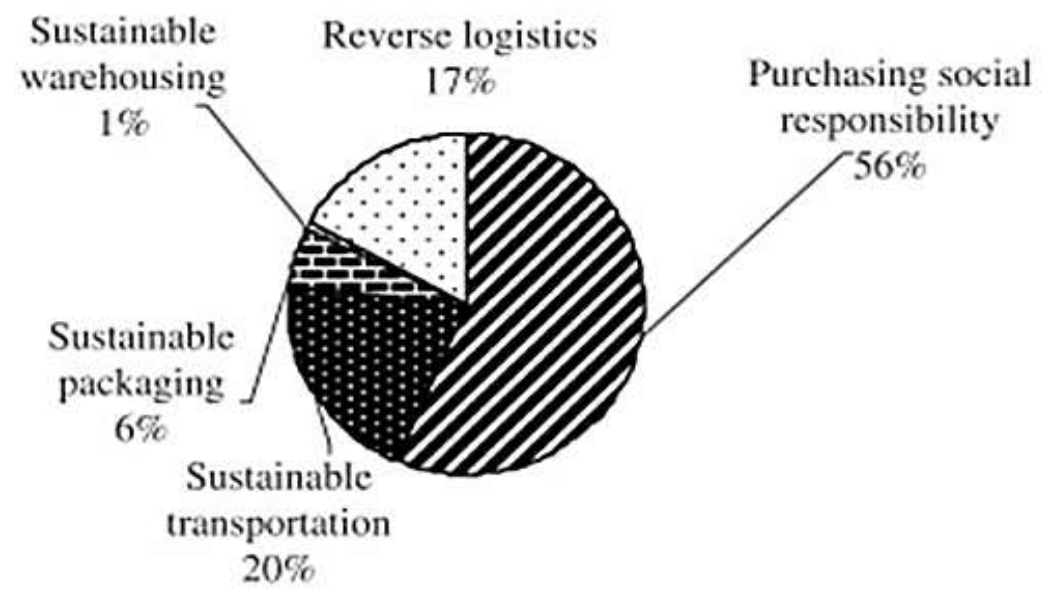

Fig. 1 Warehouse construction sustainability considerations (\%) Source: Ciliberti, Pontrandolfo and Scozzi (2008), pp. 97.

A system of certification for environmentally sustainable warehouse buildings is limited in documentation as produced by American LEED (Leadership in Energy and Environmental Design), British BREEAM (Building Research Establishment Environmental Assessment Method), French HQE (Haute Qualité Environnementale or German DGNB(Deutsche Gesellschaft fur 
Nachhaltiges Bauen) or American WELL Cerifield Gold (which has been developed in such a way that it can be used in combination with other systems such as LEED). However, the criteria among these and other certification organization is constantly increasing. In the warehouse sector, unlike the office sector, certification of facilities is the exception rather than the rule. For logistics tenants, the certificate results in higher rent. Therefore, logistic clients interested in short-term rent do not see a significant benefit to having a building environmentally or sustainably certified.

Work on the issues of sustainable warehouses undertaken by Foroozesh, Tavakkoli-Moghaddam and Mousavi (2018) and others has focused on issues of sustainable site selection for a warehouse (storage unit or magazine). Tan, Daud and Sundaram (2010) created a model to simulate the complex interrelationships between the social, economic and environmental factors related to warehouse management. Boenziet al. (2015) has taken up the topic of optimizing energy consumption during order pick-up. It is estimated that up to $55 \%$ of the total energy consumed during warehouse operation is spent during order pick-up. This is an extremely important aspect. This study simulated the selection of different types of forklift trucks and their routes for energy assessment. Andriansyah, Etman and Rooda (2009) have dealt with a similar topic. This publication developed a practical method to monitor the real-time performance of warehouses, such as any deviation from the expected performance can be detected in a timely manner during the order pick-up. Jia, Ching and Norida (2019) examined factors related to the implementation of green warehouses, i.e. government involvement, customers, suppliers, managers, employee involvement and technological innovations. Wang and $\mathrm{Li}$ (2017), on the other hand, proved that thanks to the distillation system (proper air mixing), energy savings can reach up to $40 \%$. The Wang and Li study emphasized that the degree of thermal stratification varies greatly depending on the method of heating in the warehouse, the type of radiators and the number and distribution of heat sources. Therefore, to avoid concentrated heat sources, a dedicated air distribution system is preferred. Yadav, Swami and Ahlawa (2018) proposed a method to optimize stock levels which reduce the negative environmental effects resulting from excessive energy consumption required for maintenance. The proposed method uses Particle Swarm Optimization (PSO) to study the stock level needed for essential green inventory control. Nia, Far and Niaki (2015) have developed a multi-item economic order quantity (EOQ) model with a single-buyer single-supplier supply chain using a green vendor managed inventory (VMI) policy. Abreu et al. (2019) have proven that the right choice of method to test the quality of the product stored in the warehouse allows for a better assessment of their properties and the choice of packaging that better protects the product in the warehouse and thus minimizes waste. Bortolini et al. (2017) developed a model by which they measured the energy consumption of mechanized warehouses depending on the specific operational solutions of the equipment. Facchini et al. (2016) identified the best material handling equipment (MHE) to minimize the carbon footprint of inbound logistic 
activities, based on the type of the warehouse (layout, facilities and order-picking strategy) as well as the weight of the loads to be handled. Meneghetti and Monti (2014) offers a decision-making model for configuring storage solutions in terms of energy consumption and carbon emissions. Trautrims (2017) in turn, addresses both social and environmental issues

In the following study, attention will focus on one aspect of sustainable storage management, i.e. energy optimization in storage facilities based on the use of photovoltaic (PV) panels. These considerations are in addition to the studies already indicated and their conclusions should be considered from the point of view of all possible environmental measures taken in relation to storage facilities and entire supply chain.

\section{METHODOLOGY OF RESEARCH - CASE STUDY}

Most warehouses in the United States and European countries are one-story facilities located in secluded areas near the intersection of highway systems to accommodate high truck-traffic demand. Warehouse facilities usually use a large amount of electricity for the purpose of heating, ventilation and climate control. A large amount of electric power is needed to provide appropriate lighting. Electric power is also needed for electric merchandise-handling equipment as well as robotics used to load and unload trucks. One-story buildings in secluded locations are very appropriate for the installation of photovoltaic power-generation systems. A flat roof on a large storage warehouse can normally accommodate large scale photovoltaic systems to meet the entire energy needs of the warehouse facility.

It has been proposed that H\&W Warehouse install a $3 \mathrm{MW}$ photovoltaic (PV) system to generate electricity. The system would be connected to the grid. The surplus electric energy could be sold to the power company. By using a PV calculator available through the National Renewable Energy Laboratory (NREL) website, https://pvwatts.nrel.gov/pvwatts.php, as shown in Table 1, a $3 \mathrm{MW}$ photovoltaic system would generate 4,044,097 kWh/year (about 14.6 terajoules). (NREL is a national laboratory of the U.S. Department of Energy, Office of Energy Efficiency and Renewable Energy that is operated by the Alliance for Sustainable Energy, LLC.)

According to the National Renewable Energy Laboratory, the average retail electricity rate for commercial customers is $0.11 \$ / \mathrm{kWh}$.

When the photovoltaic system would be installed, the annual monetary saving to $\mathrm{H} \& \mathrm{~W}$ Warehouse would be $\$ 444,855$. The predicted monthly energy generation is shown in Table 1 and it is followed by the technical data of the PV system (Table 2). 
Table 1 Electric energy-generation data calculated using PV Watts Calculator

\begin{tabular}{lccc}
\hline Month & Solar Radiation $\left(\mathrm{kWh} / \mathrm{m}^{2} /\right.$ day $)$ & AC Energy $(\mathrm{kWh})$ & Value $(\$)$ \\
\hline January & 3.01 & 235,447 & 25,899 \\
\hline February & 4.03 & 278,192 & 30,601 \\
\hline March & 4.84 & 364,201 & 40,062 \\
\hline April & 5.67 & 399,822 & 43,980 \\
\hline May & 5.85 & 419,657 & 46,162 \\
\hline June & 6.26 & 427,233 & 46,995 \\
\hline July & 6.38 & 437,848 & 48,163 \\
\hline August & 6.04 & 419,185 & 46,110 \\
\hline September & 5.26 & 356,810 & 39,249 \\
\hline October & 4.05 & 296,227 & 32,584 \\
\hline November & 3.24 & 233,817 & 25,719 \\
\hline December & 2.65 & 175,697 & 19,326 \\
\hline Annual & 4.77 & $4,044,097^{\star}$ & $\$ 444,855$ \\
\hline
\end{tabular}

Source: Authors' calculations

* System output may range from 3,911,976 to 4,229,626 kWh per year near this location. The estimate for the value of this energy is the product of the $A C$ energy and the average retail electricity rate.

Table $2 \mathrm{H} \&$ W Warehouse location information and PV system specifications

\begin{tabular}{|l|l|}
\hline Requested Location & New Jersey \\
\hline Latitude & $40.13 \mathrm{~N}$ \\
\hline Longitude & $74.66 \mathrm{~W}$ \\
\hline PV System Specifications (Commercial) & \\
\hline DC System Size & $3000 \mathrm{~kW}$ \\
\hline Module Type & Premium \\
\hline Array Type & Fixed (roof mount) \\
\hline Array Tilt & $20^{\circ}$ \\
\hline Array Azimuth & $180^{\circ}$ \\
\hline System Losses & $14.08 \%$ \\
\hline Inverter Efficiency & $96 \%$ \\
\hline DC to AC Size Ratio & 1.2 \\
\hline
\end{tabular}




\section{Economics}

\begin{tabular}{ll}
\hline Average Retail Electricity Rate & $0.11 \$ / \mathrm{kWh}$ \\
\hline Performance Metrics &
\end{tabular}

Capacity Factor

$15.5 \%$

Source: Authors' compilation and recommendations based on https://pvwatts.nrel.gov. DOA:02.25.2020.

The environmental benefits of the proposed $3 \mathrm{MW}$ solar photovoltaic (PV) power system has been determined using the Greenhouse Gas Equivalency Calculator available on the Environmental Protection Agency (EPA) website, https://developer.epa.gov/greenhouse-gas-equivalencies-calculatorwidget/.DOA:02.25.2020.

Based on the electric energy usage equal to $4,044,097 \mathrm{kWh}$, the greenhouse gas emission will be lowered by 2,857 tons of carbon dioxide. This reduction of greenhouse gas emissions is equivalent to the following:

- 609 passenger vehicles driven for one year

- 7,114,354 miles driven by an average passenger vehicle

- 322,616 gallons of gasoline consumed

- 281,639 gallons of diesel consumed

- 3,159,134 pounds of coal burned

- 38 tanker trucks worth of gasoline

- 331 homes' energy use for one year

- 485 homes' electricity use for one year

- 15.8 railcars worth of coal burned

- 6,638 barrels of oil consumed

- 117,206 propane cylinders used for home barbeques

- 0.0007 coal-fired power plants in one year

- 365,645,670 number of smartphones charged

The amount of greenhouse gas emissions avoided is equivalent to the following:

- 975 tons of waste recycled instead of landfilled

- 139 garbage trucks of waste recycled instead of landfilled

- 121,993 trash bags of waste recycled instead of landfilled

- 0.619 wind turbines running for a year

- 108,919 incandescent lamps switched to LEDs

The amount sequestered is equivalent to the following:

- 47,408 tree seedlings grown for ten years

- 3,744 acres of United States forests in one year

- 19.4 acres of United States forest preserved from conversion to cropland in one year

It is expected that the cost of energy will increase approximately $4 \% / y e a r$ (with inflation). 
$\mathrm{H} \& \mathrm{~W}$ Warehouse will be considering this new project. The project will be evaluated to be sure that it will be a profitable venture for the company.

The first step is to provide an analysis of the estimated cash flows for the project and an evaluation of the project's merit using appropriate capital budgeting techniques.

\section{DESCRIPTION OF THE NEW PROPOSED PROJECT BY H\&W WAREHOUSE - RESULTS OF RESEARCH AND DISCUSSION}

As a part of its corporate responsibility of protecting the environment, it has been proposed that H\&W Warehouse shall install a solar photovoltaic system on the rooftop of one its one-story building. It is proposed that H\&W Warehouse would install a $3 \mathrm{MW}$ photovoltaic (PV) system. This system would be connected to the grid, so that during the day, the surplus of energy will be sent to the grid. During the night, the electric energy needed will be drawn back from the grid. The grid will be used as energy storage from the day to night. The electric meter installed by the power company will measure the net energy use.

$\mathrm{H} \& \mathrm{~W}$ Warehouse will be paying only for the net energy use. The electric energy produced by this photovoltaic system will result in a significant cash flow for the next twenty years as shown in Table 4.

The technical life expectancy of the solar panels is approximately forty years. However, after twenty years, the solar panels start to lose efficiency. Taking this under consideration, it would be desirable to have a payback of no more than twenty years.

The approximate cost of installation of a 3MW solar photovoltaic (PV) system is $\$ 9 \mathrm{M}$. (This includes the PV panels, power invertors, hardware as well as the cost of labor.)

According to the United States Internal Revenue Service (IRS), the depreciation for a solar PV system is in Table 3.

In the $1^{\text {st }}$ year, $30 \%$ is recovered directly as a credit against the tax liability for the year of installation.

Table 3 Depreciation rate for PV systems for commercial customers

\begin{tabular}{|c|c|}
\hline Year & Depreciation Rate (\%) \\
\hline 1 & $20 \%$ \\
\hline 2 & $32 \%$ \\
\hline 3 & $19.2 \%$ \\
\hline 4 & $11.5 \%$ \\
\hline 5 & $11.5 \%$ \\
\hline 6 & $5.8 \%$ \\
\hline
\end{tabular}

Source: United State Internal Revenue Service.(https://www.irs.gov/publications/p946.

DOA:02.25.2020.)

The law allows $85 \%$ depreciation of the full-system cost (rather than 70\%).

A $3 \mathrm{MW}$ (megawatt) system is expected to generate $4,044,097 \mathrm{kWh} / \mathrm{year}$ (according to PV Watts calculator.)

The amount of gross sale income would be $\$ 444,855$. 
To determine the cost effectiveness of the PV system installation, the following financial calculations were performed.

\section{Estimating the Cash Flow}

\section{Initial Outlay}

$\$ 9,000,000-2,700,000=\$ 6,300,000$

where,

Cost of the PV system $=\$ 9,000,000$

Immediate tax credit for that year $=\$ 2,700,000$

Terminal Cash Flow $=0$

Cost of disposal is equal to the value of the salvage.

Operating cash flow for the next twenty years as well as the depreciation of the equipment is shown below.

Table 4 Operating cash flow generated by the PV system

\begin{tabular}{|c|c|c|c|}
\hline $\begin{array}{c}\text { Year } \\
\text { of Operation }\end{array}$ & $\begin{array}{c}\text { Income before } \\
\text { Tax (EBIT) }\end{array}$ & $\begin{array}{c}\text { Operating Cash Flow } \\
\text { (includes depreciation and taxes) }\end{array}$ & Depreciation \\
\hline 1 & $\$ 444,855$ & $\$ 755,425$ & $\$ 1,260,000$ \\
\hline 2 & $\$ 462,649$ & $\$ 1,054,475$ & $\$ 2,016,000$ \\
\hline 3 & $\$ 481,155$ & $\$ 758,692$ & $\$ 1,209,600$ \\
\hline 4 & $\$ 500,401$ & $\$ 585,592$ & $\$ 724,000$ \\
\hline 5 & $\$ 520,417$ & $\$ 474,240$ & $\$ 724,000$ \\
\hline 6 & $\$ 541,234$ & $\$ 348,425$ & $\$ 365,400$ \\
\hline 7 & $\$ 562,883$ & $\$ 362,361$ & $-0-$ \\
\hline 8 & $\$ 585,398$ & $\$ 376,855$ & $-0-$ \\
\hline 9 & $\$ 608,814$ & $\$ 391,929$ & $-0-$ \\
\hline 10 & $\$ 633,167$ & $\$ 407,606$ & $-0-$ \\
\hline 11 & $\$ 658,494$ & $\$ 423,911$ & $-0-$ \\
\hline 12 & $\$ 684,833$ & $\$ 440,867$ & $-0-$ \\
\hline 13 & $\$ 712,227$ & $\$ 458,502$ & $-0-$ \\
\hline 14 & $\$ 740,716$ & $\$ 476,842$ & $-0-$ \\
\hline 15 & $\$ 770,344$ & $\$ 495,916$ & $-0-$ \\
\hline 16 & $\$ 801,158$ & $\$ 515,752$ & $-0-$ \\
\hline 17 & $\$ 833,204$ & $\$ 536,382$ & $-0-$ \\
\hline 18 & $\$ 866,532$ & $\$ 557,838$ & $-0-$ \\
\hline 19 & $\$ 901,194$ & $\$ 580,151$ & $-0-$ \\
\hline 20 & $\$ 937,242$ & & \\
\hline
\end{tabular}

Source: Authors' elaboration

It has been assumed that the cost of electricity will increase $4 \% / y e a r$ due to inflation.

To calculate the incremental operating cash flow.

Incremental Operating Cash Flow $=\Delta \mathrm{EBIT}(1-\mathrm{T})+\Delta$ Depreciation $\cdot \mathbf{T}$ where:

$\mathrm{EBIT}=$ Income before tax;

$\mathrm{T}=38.1 \%$ (combined state and federal tax rate/New Jersey and United States)

To calculate the Weighted Average Cost of Capital (WACC)

$$
W A C C=\left(W_{d} \cdot k d T\right)+\left(W_{p s} \cdot k p s\right)+\left(W_{e} \cdot k e\right)
$$

Assume,

Debt $=40 \%$

$\mathrm{Wd}_{\mathrm{d}}=0.40$ 
Preferred stock $=10 \%$

$\mathrm{W}_{\mathrm{ps}}=0.1$

Common equity $=50 \%$

$\mathrm{w}_{\mathrm{e}}=0.5$

To calculate the cost of debt after tax.

$$
\begin{gathered}
\mathbf{K}_{d T}=\mathbf{k}_{\mathbf{d}}(\mathbf{1}-\mathbf{T}) \\
\mathrm{k}_{d T}=7 \% \cdot(1-0.381)
\end{gathered}
$$

$\mathrm{kdT}=4.33 \%$

where:

$k_{d}=$ present of cost of debt

Assume,

$\mathrm{k}_{\mathrm{d}}=7 \%$

$\mathrm{T}=38.1 \%$ (present tax rate)

$\mathrm{kdT}=$ cost of debt after tax

To calculate the cost of the preferred stock.

$$
\begin{gathered}
\mathbf{k p s}_{\mathrm{p}}=\mathbf{D}_{\mathrm{ps}} \div \mathbf{P} \\
\mathrm{k}_{\mathrm{ps}}=2.64 \div 51 \\
\mathrm{~K}_{\mathrm{ps}}=5.18 \%
\end{gathered}
$$

where:

$D_{p s}=$ dividend paid on preferred stock $(\$ 2.64)$

$\mathrm{P}=$ price of preferred stock $(\$ 51)$

$\mathrm{kps}=$ cost of preferred stock

Calculate the cost of retained earnings by using three different methods.

\#1 Bond yield + Risk Premium Method

$$
\begin{gathered}
\mathbf{k}_{e}=\text { Bond yield }+ \text { Risk premium } \\
k_{e}=2 \%+3.5 \% \\
k_{e}=5.5 \%
\end{gathered}
$$

where:

$\mathrm{k}_{\mathrm{e}}=$ cost of retained earnings

Bond yield $=2 \%$ (assume)

Risk premium $=3.5 \%$ (assume)

\#2 Capital Asset Pricing Model (CAPM Approach)

$$
\begin{gathered}
\mathbf{K e}_{\mathbf{e}}=\mathbf{k} \mathbf{r f}+(\mathbf{k m}-\mathbf{k r f}) \boldsymbol{B} \\
\mathrm{k}_{\mathrm{e}}=2 \%+(5.5 \%-2 \%) 1.27 \\
\mathrm{ke}_{\mathrm{e}}=6.45 \%
\end{gathered}
$$

where,

$\mathrm{k}_{\mathrm{e}}=$ cost of retained earnings

$\mathrm{k}_{\mathrm{rf}}=$ risk-free rate (Assume $2 \%$ )

$\mathrm{k}_{\mathrm{m}}=$ market return (Assume 5.5\%)

$B=$ risk of portfolio (1.27 for the portfolio)

\#3 Discounted Cash Flow Model (DCF Approach)

$$
\begin{aligned}
& \mathbf{k}_{\mathbf{e}}=\left(\mathbf{D}_{\mathbf{1}} \div \mathbf{P}_{\mathbf{o}}\right)+\mathbf{g} \\
& \mathrm{k}_{\mathrm{e}}=(\$ 3.8 \div \$ 137)+0.017 \\
& \mathrm{k}_{\mathrm{e}}=0.045(4.5 \%)
\end{aligned}
$$

where: 
$\mathrm{D}_{\mathrm{I}}=$ expected dividend $(\$ 3.8)$

$P_{0}=$ current stock price $(\$ 137.75)$

$\mathrm{g}=$ predicted growth rate (Assume 1.7\%)

Calculating the Average Value of the Cost of the Retained Earning ( $\left.\mathbf{k}_{\mathbf{e}}\right)$

$k_{e}=($ Bond yield $/$ Risk premium + CAPM Approach + DCF Approach $) \div 3$

Calculating WACC

$$
\begin{gathered}
\text { ke }(\text { average })=(5.5 \%+6.45 \%+4.5 \%) \div 3 \\
\text { ke }(\text { average })=5.5 \%
\end{gathered}
$$

$W A C C=\left(w_{d} \cdot k_{d T}\right)+\left(w_{p s} \cdot k_{p s}\right)+\left(w_{e} \cdot k_{e}\right)$

$$
\begin{gathered}
\text { WACC }=(0.4 \cdot 4.33)+(0.1 \cdot 5.18)+(0.5 \cdot 5.5) \\
\text { WACC }=1.73+0.518+2.75 \\
\text { WACC }=5 \%
\end{gathered}
$$

\section{Capital Budgeting}

\section{Net Present Value (NPV)}

$$
\mathrm{NPV}=-\mathrm{CF}_{\circ}+\mathrm{CF}_{1} /(1+\mathrm{r})+\mathrm{CF}_{2} /(1+\mathrm{r})^{2} \quad \mathrm{CF}_{20} /(1+\mathrm{r})^{20}
$$

Table 5 contains the adjusted cash flows assuming " $r$ " equals $0.05 . \mathrm{CF}_{\mathrm{o}}$ is $\$ 6,300,000$ (initial outlay.

Table 5 Adjusted cash flow for 20 years of operation of the PV system

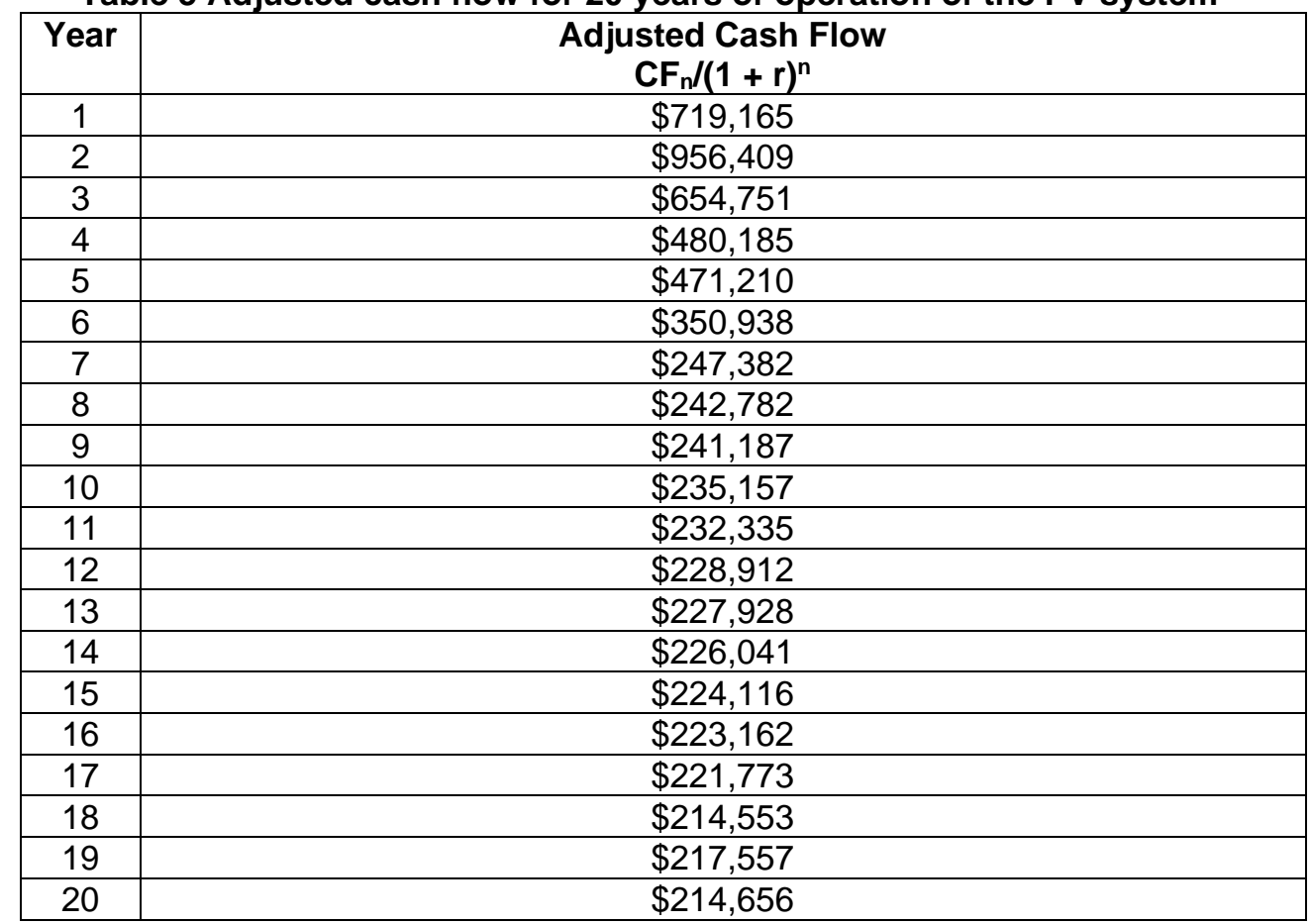

Source: Authors' calculations

Based on the calculated incremental cash flows, five indicators were calculated which describe the economic validity of the project. Those indicators are as follows:

1. Net Present Value (NPV)

NPV $=\$ 531,522$

2. Internal Rate of Return (IRR)

$6.239 \%$

3. Profitability Index (PI) 


$$
\begin{aligned}
& \mathrm{PI}=\mathrm{PV} \text { of the future cash flows } \div \text { Initial Cost } \\
& \mathrm{PI}=1.084
\end{aligned}
$$

4. Regular Payback

Payback time $=$ Number of years prior to recovery

Payback time $=11.44$ years

5. Discounted Payback

Payback time $=17.53$ years

The net present value (NPV) of the PV project is $\$ 531,522$. A positive net present value is being considered as the most important indicator for either accepting or rejecting the project. The calculated net present value indicates that the project will contribute over $\$ 531,522$ to the company's assets.

A discounted payback time of 17.53 years seems to be longer than the average payback time of industry projects. However, it must be taken into consideration that the installation of a PV system is normally a low risk investment.

\section{RESULTS OF RESEARCH AND DISCUSSION}

It should be noted that the implementation of photovoltaic solutions is one of many elements by which pro-environmental effects can be achieved. Therefore, decisions on the creation of green warehouses require a systemic approach considering all aspects that can improve the environmental performance of warehouses.

Resource-saving measures (e.g. through covering floors and walls with reflective paint, appropriate adjustment of artificial light, forced air circulation, i.e. so-called distillation can be considered. Other activities to reduce carbon dioxide emissions (e.g. by purchasing non-emission forklifts, locating warehouses close to public transport hubs and the homes of most employees) can also be considered. Solutions may also include projects that improve the environmental performance of the storage facilities e.g. through placing wind screens, biologically active areas, i.e. areas with earth surface arranged in such a way as to ensure the natural vegetation of plants, as well as terraces and roofs with such surface at a statutory area. To create an ecological warehouse, it is also possible to undertake other types of undertakings such as waste compression, reduction of vibrations and noises.

The analyses carried out on the use of natural solar energy fall within the group of solutions which include alternative sources of energy or water e.g. through collecting waste water, using wind energy or building a so-called thrombe wall, which is used to air condition rooms in summer and to heat them in winter.

Each of these elements contributes to saving various resources. For example, the establishment of biologically active areas involves reducing water consumption and $\mathrm{CO}_{2}$ emissions. The use of biologically active walls is associated with the reduction of $\mathrm{CO}_{2}$ and energy consumption. Environmentally friendly internal transport can contribute to reducing energy and $\mathrm{CO}_{2}$ emissions.

Of these three main reduction considerations, the greatest potential lies in solutions to save energy. Therefore, further research on the possibility 
of using photovoltaic panels on warehouse roofs is justified and needed. The fact that there are a wide variety of countries with a similar latitude shows that the potential use of solar photovoltaic system usage at warehouse facilities has not yet been exploited.

Further analyses should therefore go into the diagnosis of what kind of environmental projects are carried out alongside the implementation of photovoltaic panels. What other projects could be implemented along with a solar photovoltaic system?

What are the financial advantages and disadvantages to installing a solar photovoltaic system and creating green warehouses? Is the use of solar energy characteristic for green warehouses with a higher degree of advancement also for other green investments?

What barriers, apart from financial ones, stand in the way of investments in solar photovoltaic panels? Is it possible from the structural side of buildings and roofs to install a solar photovoltaic system?

The targeted construction of grid of connections between individual elements is creating green warehouses and the links between them. The barriers to their implementation may provide a valuable reference base for decision-making processes by business practitioners, as well as a good reference point for creating research questions and models, hypotheses and triangulation studies in addition to already existing empirical research.

\section{POTENTIAL LIMITATIONS}

The potential limitations of installing PV systems on the rooftop of a warehouse are as follows:

- Additional load on the roof;

(This factor is normally not a problem due to the existing standards for the roof load- capacity requirements. The solar PV system has a very low load distribution per sq./ft. It is recommended that a structural engineer do an inspection of the roof structure before installing the PV system.)

- Additional hazard in case of fire;

(The local fire department needs to be notified and have a plan for disabling the PV system during the extinguishing of a fire. Many fire departments already have adequate training in that area.)

- Additional hazard in case of a tornado or hurricane;

(PV systems are mounted to withstand high winds. In an extreme wind situation, the PV system can create an additional hazard.)

- Cost factor and reliability;

(The cost factor and system reliability are still major limitations. The cost factor, however, is significantly decreasing and the reliability has significantly increased. With the proper tax incentives, the PV becomes economically feasible.)

- Requirement for grid connection. 
(A large PV system needs to be grid connected, so the electric energy can be traded back-and-forth with the grid.)

Among other things, DB Schenker has opened its first 100 per cent solarpowered warehouse in the United Emirates in Dubai. The Amazon is also in the process of developing a project on the roofs of a logistics centre in the UK in the city of Tilbury. This project will also include other facilities. the logistics centre. Prologis Park Budapest-Harbor is the first logistics centre in the world to use solar energy from pavement-mounted panels. However, the lack of detailed data on this topic makes comparative analyses impossible. Therefore, the results obtained in the future should be confronted with scientific analyses of already implemented solutions.

\section{CONCLUSION}

The project of installing a roof-mounted solar photovoltaic (PV) on the top of the $\mathrm{H} \& \mathrm{~W}$ warehouse seems to be a valuable investment from the financial perspective. The payback time is 11.44 years (discounted payment 17.53 years). The calculated profitability index (PI) is 1.084. The calculated financial benefits are affected by tax laws, depreciation schedule and the cost of electricity. Therefore, the calculated financial benefits of the project will not be directly transferable to the existing conditions in other countries. The weather conditions and the amount of sun exposure between the United States and other regions of the world may vary and the amount of energy generated by the PV system may be different. The calculations to determine the effectiveness of the PV system need to be location specific and should consider sun exposure, cost of energy as well as tax incentives. Payback time and profitability index can be different for different locations. Therefore, each project will need to be evaluated individually. The environmental benefits of the project described in the paper have been previously listed. The environmental benefits are equivalent to taking 609 passenger vehicles off the road for one year. The amount of energy generated by the project could meet the entire energy demand for 331 homes per year. The amount of energy would also be equivalent to burning 15.8 railroad cars of coal for one year. The amount of carbon dioxide released to the atmosphere would be reduced by 2857 tons. As shown, the project is making a significant impact on protecting the environment and lowering the carbon footprint.

\section{REFERENCES}

Abreu, G.F. Borém, F.M., Oliveira, L.F.C., Almeida, M.R. and Alves, A.P.C.(2019) 'Raman spectroscopy: A new strategy for monitoring the quality of green coffee beans during storage', Food Chemistry, 287, pp. 241-248. doi:10.1016/j.dci.2019.103526

Andriansyah, R., Etman, L.F.P. and Rooda, J.E. (2009) 'On sustainable operation of warehouse order picking systems', Proceedings of the XIV Summer School 'Francesco Turco', September, 15-19, 2009, Porto Giardino, Italy, pp. IV.16-IV.23.

Boenzi, F., Digies, S., Facchin, F., Mossa, G. and Mummolo, G. (2015) 'Greening activities in warehouses: Amodel for identifying sustainable strategies in material 
handling', Annals of DAAAM and Proceedings of the International DAAAM Symposium, pp. 980-988. doi: 10.2507/26th.daaam.proceedings.138

Bortolini, M., Faccio, M., Ferrari, E., Gamberi, M. and Pilati, F. (2017) 'Time and energy optimal unit-load assignment for automatic S/R warehouses', International Journal of Production Economics, 190, pp. 133-145. doi:10.1016/j.ijpe.2016.07.024

Ciliberti, F., Pontrandolfo, P., Scozzi, B. (2008) 'Logistics social responsibility: Standard adoption and practices in Italian companies', International Journal of Production Economics, pp. 113(1), 88-106. doi.org/10.1016/j.jpe.2007.02.049

Facchini, F., Mummolo, G., Mossa, G., Digiesi, S., Boenzi, F. and Verriello, R. (2016) 'Minimizing the carbon footprint of material handling equipment: Comparison of electric and LPG forklifts', Journal of Industrial Engineering and Management, 9(5), pp.1035-1046. doi:10.3926/jiem.2082

Foroozesh, N., Tavakkoli-Moghaddam, R. and Mousavi, S. (2018) 'A novel group decision model based on mean-variance-skewness concepts and interval-valued fuzzy sets for a selection problem of the sustainable warehouse location under uncertainty', Neural Computing and Applications, 30(11), pp. 3277-3293. doi:10.1007/s00521-017-2885-Z

He, B., Liu Y., Zeng, L., Wang, S., Zhang, D. and Yu, Q. (2019) 'Product carbon footprint across sustainable supply chain', Journal of Cleaner Production, 118320. doi:10.1016/j.jclepro.2019.118320

Jia, X.L., Ching, X.K. and Norida, W.S. (2019) 'A Study on the Factors Influencing Green Warehouse Practice', E3S Web of Conferences, 01 January 2019, 136, pp.01040. doi.org/10.1051/e3sconf/201913601040

Mangina, E., Narasimhan, P.K., Saffari, M. and Vlachos, I. (2020) 'Data analytics for sustainable global supply chains', Journal of Cleaner Production, 120300. doi:10.1016/j.jclepro.2020.120300

Maryniak, A. (2017) Zarządzanie zielonym łańcuchem dostaw, Wydawnictwo Uniwersytetu Ekonomicznego w Poznaniu, Poznań.

Meneghetti, A. and Monti, L. (2014) 'Greening the food supply chain: an optimisation model for sustainable design of refrigerated automated warehouses', International Journal of Production Research, 53(21), 6567-6587. doi:10.1080/00207543.2014.985449

Moktadir, M.A., Ali, S. M., Jabbour, C.J.C., Paul, A., Ahmed, S., Sultana, R. and Rahman, T. (2019) 'Key factors for energy-efficient supply chains: Implications for energy policy in emerging economies', Energy, 11612. doi:10.1016/j.energy.2019.116129

Nia, A.R., Far, M. H. and Niaki, S.T.A. (2015) 'A hybrid genetic and imperialist competitive algorithm for green vendor managed inventory of multi-item multiconstraint EOQ model under shortage', Applied Soft Computing Journal, 30, pp. 353-364. doi.org/10.1016/j.asoc.2015.02.004

Rajesh, R. (2020) 'Sustainable supply chains in the Indian context: An integrative decision-making model', Technology in Society, 101230. doi:10.1016/j.techsoc.2020.101230

Tan, K.S., Daud, A.M. and Sundaram, D. (2010) 'Sustainable enterprise modelling and simulation in a warehousing context', Business Process Management Journal, 16(5), pp. 871-886. doi.org/10.1108/14637151011076511

Trautrims, A. (2017) 'Sustainable warehousing' in Grant, D.B., Trautrims, A. and Wong C.Y. Sustainable logistics and supply chain management: principles and practices for sustainable operations and management, Kogan Page, Londeon, New York, New Delhi, 92-118.

Yadav, G., Luthra, S., Jakhar, S., Mangla, S.K. and Rai, D.P. (2020) 'A framework to overcome sustainable supply chain challenges through solution measures of industry 4.0 and circular economy: An automotive case', Journal of Cleaner Production, 120112. doi:10.1016/j.jclepro.2020.120112 
Yadav, A.S., Swami, A. and Ahlawa, N. ( 2018) 'A Green supply chain management of Auto industry for inventory model with distribution centers using Particle Swarm Optimization', Self organizology, 5(3-4), pp. 10-18.

Wang, L.L. and Li, W. (2017) 'A study of thermal destratification for large warehouse energy savings', Energy and Buildings, 153, pp.126-135. doi.org/10.1016/j.enbuild.2017.07.070

https://developer.epa.gov/greenhouse-gas-equivalencies-calculatorwidget/.DOA:02.25.2020.

https://pvwatts.nrel.gov. DOA:02.25.2020 .

https://www.irs.gov/publications/p946. DOA:02.25.2020.

\begin{abstract}
.
Sustainability and eco-friendliness of the chain of supply is a subject of interest among many researchers. New eco-friendly solutions are being implemented in production, storage, and transportation of the entire chain of supply. This study focuses on pro-environmental solutions related to warehouse management. The publication describes a project of installing a solar photovoltaic (PV) system to generate electric power at the H\&W Warehouse in New Brunswick, New Jersey. The purpose of this publication is to demonstrate the financial and environmental benefits of using sustainable forms of energy. The environmental benefits were calculated from the perspective of lowering the amount of carbon dioxide $\left(\mathrm{CO}_{2}\right)$ released into the atmosphere. The financial benefits were determined by calculating the net present value (NPV), internal rate of return (IRR) and profitability index (PI) as well as regular and discounted payback. A computer simulation was being used as the research method. Calculations included in the publication have proven that the project being considered is beneficial from the financial and environmental perspectives.
\end{abstract}

Keywords: CSR, green warehouses, photovoltaic system, sustainable supply chain 